Underhill and Kelly (1993:418) observed that "further attempts may be made to intraduce this model [Odco precedents] . . . now that the possibility of future success is legally assured'. With the development of the agency contracting, their forecast is being borne out, and do-it-yourself labour-market reform is under way in Australia.

\title{
Reference
}

Underhill, E. \& D. Kelly (1993), 'Eliminating Tradicional Employment: Troubleshooters Available in the Building and Meat Industries', Journal of Industrial Relations 35(3): 398-423.

Ken Phillips is a Melbourne-based employment and workplace reform consultant.

\section{Overseas Assembly Provisions: A Hidden Producer Subsidy}

\section{Darren Kennedy}

$\mathrm{O}$ verseas Assembly Provisions (OAPs) are a recent policy initiative in the textile, clothing and footwear (TCF) industries. OAPs permit approved TCF manufacturers to assemble garments overseas using Australian fabrics and to import the final products back into the country at a concessional rate of duty. The introduction of OAPs acknowledges that Australia has a high labour cost disadvantage relative to other TCF manufacturers, and attempts to improve the competitiveness of its TCF sector by shifting production away from labour-intensive activities. But although they allow Australian firms to benefit from lower offshore wages, OAPs tackle the existing problems created by import protection only indirectly, and do not necessarily reduce the welfare cost of the current distortions.

\section{OAPs and Protection}

OAPs are meant to discourage local labour-intensive production activity and to allow Australian firms to benefit from low foreign wages. The provisions aim to promote specialisation in other areas of the industry, such as textile manufacture and clothing design. The Textile, Clothing and Footwear Development Authority (TCFDA), which monitors industry progress under the TCF Plan, believes that Australian firms have the potential to specialise, and to become internationally competitive, in the higher value-added activities sucl as textile and clothing design, textile production, and marketing (TCFDA, 1993:12).

OAPs originated in the context of the protectionist policy that spanned the post-war years to the early 1980s. Import protection was allocated on a made-to- 
measure basis whereby assistance was granted to offset falls in the competitiveness of domestic producers. TCF imports grew rapidly in the 1970 s with the emergence of TCF industries in less developed countries. Rapid domestic wage rises and equal pay for women exacerbated the decline in TCF competitiveness. Import quotas, which were introduced in an attempt to stabilise the TCF industries in times of growing unemployment, very quickly became an integral part of the assistance package afforded to TCF manufacturers. As they were tightened throughout the late 1970 s, the effective rate of protection for clothing rose from 96 per cent in 1976 to 213 per cent in 1982 . Yet aggregate TCF employment fell by almost 60 per cent during the decade to 1982 .

Over the last decade the federal government has reversed the trend of rising protection for manufacturing industries. In 1986, when the government decided to embark on a reform program, the estimated cost to consumers of TCF protection was $\$ 1$ billion a year. The federal government announced its post-1988 TCF Plan with the broad aim of ensuring the long-term viability of Australia's TCF industries with significantly lower levels of Commonwealth assistance. The strategies adopted included phasing out quotas and reducing tariff rates to a maximum of 60 per cent by 1996. Quotas ceased in March 1993. The reform program was accelerated and extended in 1990 with tariff reductions that are now scheduled to continue until 2000 , when a maximum duty of 25 per cent will apply. So despite significant tariff reductions, the TCF industries will remain Australia's most highly protected manufacturing sectors.

OAPs were announced in the July 1992 TCF Statement as a part of a package of modifications to the TCF Plan. The amendments were introduced largely in response to the recession and its impact upon the TCF industries. OAPs began in March 1993 for a trial period of three years with five participating firms.

OAPs are not new. Other OECD nations, including Japan, Canada, USA, and the European Community, have employed OAPs since the 1970s to help their industries compete against TCF products from developing countries. TCF manufacturers in developed countries have found it increasingly difficult to compete against the significantly lower wages of developing countries (wages in China in 1992 were equivalent to US\$0.30 per hour). Such wage differentials are amplified by the labour-intensive stages of production that are typical of TCF industries.

\section{How OAPs Work}

To qualify for OAP duty concessions, firms must be Australian-owned and able to demonstrate a long-term commitment to TCF production in Australia. Approved clothing manufacturers may then assemble garments overseas and import the final product at a duty levied only on the value added offshore. OAP eligibility requires that at least 85 per cent of the fabric used in an imported garment be made in Australia. This last requirement represents an indirect form of export facilitation for the Australian textile industry.

OAPs benefit the community by discouraging domestic apparel assembly, a particularly labour-intensive production activity with a high local comparative disad- 
vantage. OAPs also reduce both the cost disability of the domestic clothing industry and the welfare burden associated with a given level of local TCF production. (The moral and political issue of whether Australia should take advantage of poor working conditions in less developed countries is not considered here.)

But this welfare gain is offset by the cost of increased activity in the high-cost domestic clothing industry. This production stimulus is provided by the cost advantages OAPs offer and the associated implicit subsidy for TCF producers to assemble garments overseas. The subsidy arises from the tariff revenue forgone when the items assembled overseas are imported duty free. Local OAP manufacturers still sell their produce at the market (tariff inclusive) price and collect the revenue that otherwise would have gone to the government. Consumers indirectly fund this subsidy because the government must compensate for the lost revenue with higher taxes in other markets or reductions in government services.

The net welfare effects of introducing a program of OAPs are determined by the relative magnitudes of the intra-industry gain of lower production costs and the efficiency losses of greater production of clothing. There is insufficient evidence available to indicate whether or not the scheme produces more total benefits than costs.

In attempting to address with OAPs the problem of a large cost disability in the process of garment assembly, the government has created further problems. Quite apart from the cost of expanding clothing production when similar products could be imported more cheaply, such expansion is generated by a subsidy that is only temporary if the trial period is not extended or if tariff reductions continue. This creates additional vested interests in favour of continued protection.

\section{The Future of OAPs}

It is uncertain whether OAPs will be renewed after the trial period ends in 1996. OAPs were introduced mainly to assist the TCF sector during the recession, when the government was under intense pressure to reduce TCF job losses but reluctant to postpone tariff reductions. This rationale suggests that, unless the government believes that real benefits have emerged from the provisions, the scheme may not continue after 1996.

Whatever the case, the only effective way of reducing the distortions and associated costs created by protection is to continue the current program of tariff reductions. Even if OAPs were to be renewed, falling tariff rates would reduce the implicit subsidy to producers. Any indirect policy tool such as OAPs will always result in unnecessary costs by not directly addressing the fundamental problem or policy decision.

\section{Reference}

Textile, Clothing and Footwear Development Authority (TCFDA) (1993), Annual Report 199293, AGPS, Melbourne.

Darren Kennedy, who was recently awarded an Honours degree in economics at The Australian National University, is now working for ABARE. 